single specimen from southeastern Alberta.) Only two specimens have been reported in the province during the last 22 years, but since it is completely nocturnal it may be more common than these few records suggest. The first one known to have been found in Saskatchewan was captured by a dog in 1933 at Shackleton. The following year a second cne was found dead on a road near Tompkins (Anderson, 1946, Catalogue of Canadian Recent Mammals). In July, the first week of 1955 , a third cne was obtained by $\mathrm{Mr}$ Michael Spies near Portreeve. A glance at a map shows that these three records of this interesting mammal fall within a circle 55 miles in diameter. in the southwest corner of the province, about 40 miles west of Swift Current. This particular species, the Ord Kangaroo Rat (Dipodomys ordii) is widely distributed over the western United States. It is reasonable to expect, therefore, that additional work will reveal the presence of Kangaroo Rats in suitable areas from Portreeve south to the border of the province. Determination of the range of this species within the province. as well as that of other mammals, is one of the important prcblems which still need to be solved. Since Kangaroo Rats live in colonies and erect large mounds of earth pierced by numerous openings they shculd not be too difficult to locate.

\section{Commensal Feeding of Muskrat and Rusty Blackbird}

\author{
By DR. R. W. NERO
}

In the dictionary commensal behavior is defined as "eating at the same table." In biology this term has been used to designate a kind of parasitism in which, however, the "host" neither loses nor gains. On November 5, 1955, I observed a good example of commensalism between a Rusty Blackbird (Euphagus carolinus) and a Muskrat (Ondatra zibethica) while hunting along the Qu'Appelle River north of Regina. Although it was cold, the temperature during the day being 15 to 20 degrees $F$. with a brisk wind blow- ing from the Northwest, the river was still open in places, a thin layer of ice extending up to 10 feet from each shore. Early in the afternoon I had several times noticed Muskrats sitting on the edge of the ice and eating. On two or three occasions a Rusty Blackbird was observed near a "rat", but since I was fresh and intent on the hunt, little attention was paid to either bird or mammal. Pacsing by the same general area later in the afternoon, being somewhat wearied and more inclined to pause occasionally, I stopped to watch a Rusty Blackbird which was moving about on the ice on the opposite shore near a rat. The latter was feeding on some dark vegetation which it had evidently just brought up from the stream bottom. As I watched, the Blackbird moved in to within 5 or 6 inches of the rat and began warily picking at the vegetation, jumping back each time the latter raised its head in an obviously aggressive gesture. The Blackbird continued to feed in a cautious manner for 2 or 3 minutes, before $I$ left. It seemed quite clear that the Blackbird was feeding on animal life which had been brought up with the vegetation, presumably crustaceans or other arthropods, or possibly snails. I am convinced that the Rusties which I had seen earlier in the afterncon were dining at the same kind cf table.

Commensal feeding involving another icterid was reported by Shelley in 1930 (Companionate feeding activities of a Spotted Sandpiper and a Red-winged Blackbird. Auk, 47 (1): 78-79). A Spotted Sandpiper (Actitis macularia), feeding on bottom-feeding larvae of the caddis-fly which it brought to shore to eat, was closely followed by a Redwing (Agelaius phoeniceus), which quickly ate the larvae which the Sandpiper occasionally discarded.

\section{Rattlesnake dens along the South} Saskatchewan River. - Mr. J. J. Deck of Mendham reports that dens of Rattlesnakes are numerous along the river hills on the north side of the Saskatchewan River near the Alberta boundary. Mr. Deck loaned to the Museum, for viewing, a film he had made showing the "rattlers" in this area. 